\title{
The cryoconite ecosystem on the Greenland ice sheet
}

\author{
Andy HODSON, ${ }^{1}$ Carl BØGGILD, ${ }^{2}$ Edward HANNA, ${ }^{1}$ Phillipe HUYBRECHTS, ${ }^{3}$ \\ Harry LANGFORD, ${ }^{1}$ Karen CAMERON,${ }^{1}$ Alexandra HOULDSWORTH ${ }^{1}$ \\ ${ }^{1}$ Department of Geography, University of Sheffield, Winter Street, Sheffield S10 2TN, UK \\ E-mail: a.j.hodson@sheffield.ac.uk \\ ${ }^{2}$ The University Centre in Svalbard (UNIS), PO Box 156, NO-9171 Longyearbyen, Norway \\ ${ }^{3}$ Earth System Sciences \& Department of Geography, Vrije Universiteit Brussel, Pleinlaan 2, B-1050 Brussels, Belgium
}

\begin{abstract}
This paper presents an assessment of biological activity associated with ice surface debris (cryoconite) at the ice-sheet scale. Estimates of the mass distribution of cryoconite over the Greenland ice sheet (GIS) and the biological activity associated with it are presented and then coupled with a surface mass-balance model to estimate total carbon fluxes due to respiration and photosynthesis. We find an average loading of $66 \mathrm{~g} \mathrm{~m}^{-2}$ at Kangerlussuaq, southwest Greenland, which compares well with recent estimates from Kronprins Christians Land $\left(17-440 \mathrm{~g} \mathrm{~m}^{-2}\right.$ : Bøggild and others, 2010) in northeast Greenland. We also report a significant microbial biomass in cryoconite at both these places $\left(10^{3}-10^{4}\right.$ cells $\left.\mathrm{mg}^{-1}\right)$ and carbon fluxes of the order of $1-3 \mu \mathrm{MC}^{-1} \mathrm{~d}^{-1}$ for both respiration and photosynthesis. The modelling indicates that total respiration and photosynthesis fluxes are likely to be $\sim 10^{1}-10^{2} \mathrm{Gg} \mathrm{Ca}^{-1}$ and thus far from trivial. However, estimation of the net ecosystem impact across the entire ice sheet on atmospheric $\mathrm{CO}_{2}$ concentrations is problematic because photosynthesis rates were almost certainly low during our field campaign. Therefore, like its water balance, the carbon balance of the GIS is now known to be important, but its accurate quantification will remain elusive until more data are forthcoming.
\end{abstract}

\section{INTRODUCTION}

Deposits of dust on the Greenland ice sheet (GIS) were sampled by N.A.E. Nordenskiöld as early as 1883. He proposed that it was 'cosmic dust' of extraterrestrial origin and gave it a suitably enigmatic name: 'cryoconite' (or 'kryokonite'). Detailed petrographic analyses of Nordenskiöld's samples were reported by Bayley (1891), who revealed that the cryoconite was an aggregation of local crystalline schist particles and organic matter. Observations of the distribution of cryoconite over the ice sheet were also described by other explorers, who suggested that local dusts were the true source, since it was most abundant near the ice-sheet margins (e.g. de Quervain, 1920). This work, along with several earlier traverses by R. Peary and F. Nansen, therefore provided the first qualitative accounts of cryoconite distribution upon the GIS. Nansen described cryoconite in a $30 \mathrm{~km}$ wide zone on the western margin of the GIS, noting its importance for forcing higher melt rates than in the east (where little cryoconite was found; Hobbs, 1910). The morphology of cryoconite holes was also measured by Nordenskiöld, von Drygalski and Nansen (von Drygalski, 1897; Hobbs, 1910). However, its microbiology was largely overlooked until after Steinböck's expedition to Disko Island, when he proposed that the GIS supported a thriving microbial ecosystem which persisted throughout glacial cycles (Steinböck, 1936; Gajda, 1958). Work then commenced upon glaciers in the Zackenberg area and more notably in the Thule area during the 1940s and 1950s (e.g. Gajda, 1958; Gerdel and Drouet, 1960), resulting in a detailed yet qualitative characterization of the habitat and the microorganisms present. A more quantitative treatment of the relationship between solar irradiance and cryoconite hole formation was then presented by Gribbon (1979), following his work in the Sermikavsak area.
The above studies are notable in that they show how important the GIS has been for initiating an interest in the microbiology of ice surface ecosystems. It is therefore remarkable that so few data are available to quantify this ecosystem at the ice-sheet scale, especially since this is almost certainly the largest cryoconite ecosystem in the Northern Hemisphere. One recent exception is the assessment by Bøggild and others (2010) of the distribution of cryoconite within different zones in Kronprins Christians Land (KPCL; Fig. 1). Another is the study by Stibal and others (2010), which shows how cryoconite biogeochemistry varies over tens of kilometres inland from the ice margin at Kangerlussuaq (KG). This paper contributes further by assessing the mass loading of cryoconite at the GIS margin in the KG and KPCL areas, by quantifying biological activity for the first time in terms of photosynthesis and respiration, and by then providing tentative estimates of the possible $\mathrm{CO}_{2}$ fluxes at the ice-sheet scale that result from this activity.

\section{FIELD SITE AND METHODS}

\section{Cryoconite mass assessment}

Mass loading of cryoconite and other surface debris was estimated using two short transect studies in the northeast and southwest margins of the ice sheet (at KPCL and KG, respectively; Fig. 1). The former transect has already been described by Bøggild and others (2010) and is of the order of $5 \mathrm{~km}$, extending from the equilibrium line to the glacier margin. This includes marginal ice with basally derived debris, Holocene blue ice with deep well-developed cryoconite holes, and then Pleistocene ice characterized by shallow cryoconite holes and dispersed cryoconite particles on the ice surface. The second transect (at KG) is just $2 \mathrm{~km}$ from the margin in an area where the equilibrium line is more than $100 \mathrm{~km}$ inland. This includes a $\sim 700 \mathrm{~m}$ 


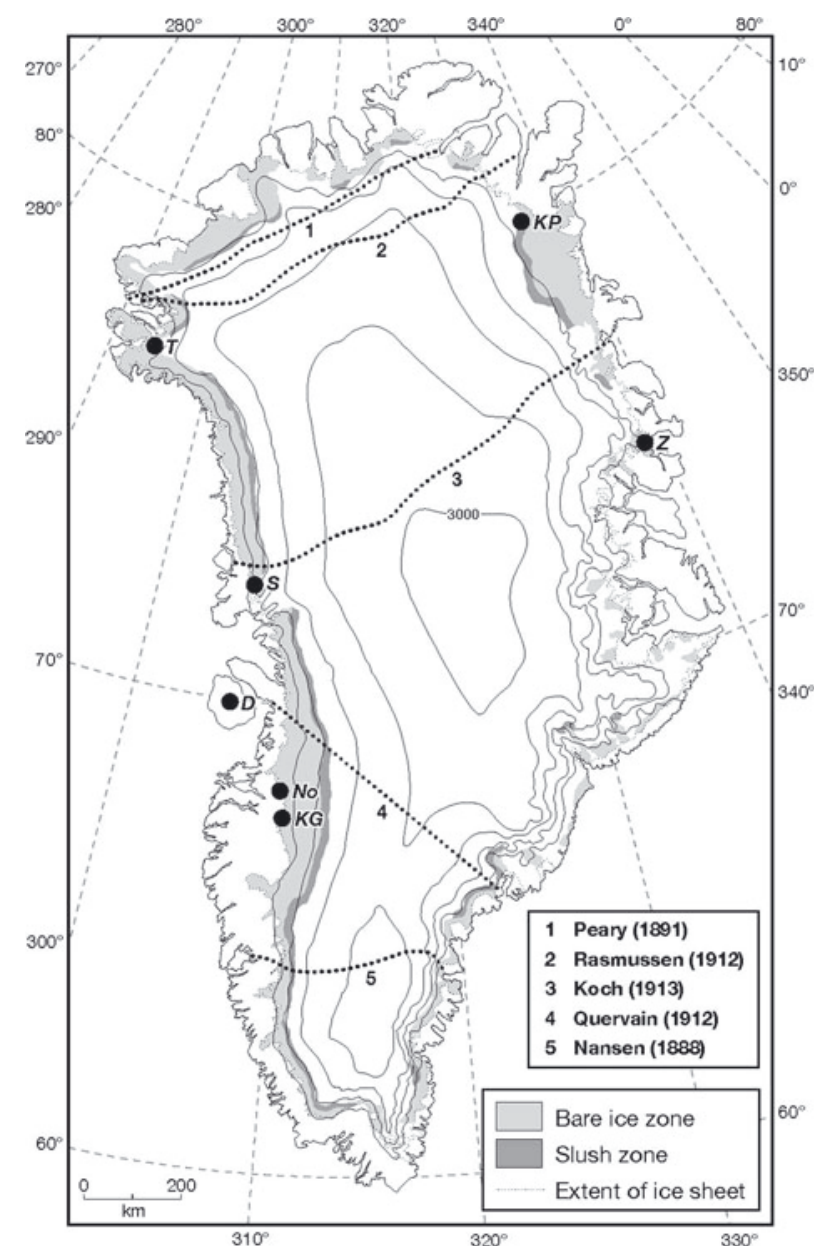

Fig. 1. Notable observations of cryoconite upon the GIS. 1-5 represent multiple traverses by the explorers named in the legend (see Hobbs, 1910). Also shown are Nordenskiöld's study area (No), Thule Ramp (T), Sermikavsak (S), the KG (KG) and KPCL (KP) transects, Steinböck's study area (D) and Zackenberg (Z). The bare ice zone and the slush zone, where biological activity is most likely, are also shown after Janssens and Huybrechts (2000).

marginal zone characterized by basally derived debris and $\sim 1300 \mathrm{~m}$ of Holocene blue ice with well-developed cryoconite holes. The mass loading of cryoconite debris on both these ice facies at KG was therefore assessed by first estimating the area of surface debris cover and then establishing the mass per unit area of cover. The former was achieved by processing 42 quadrat images of the ice surface in the marginal zone and 205 quadrat images from the blue ice zone, using Imagel software (for complete details see Irvine-Fynn and others, 2010). The mass of debris per unit area of cover was then derived after processing images of 12 cryoconite holes of different size in the same way and establishing the dry mass within them after sampling their entire contents and oven-drying them at $40^{\circ} \mathrm{C}$. For cryoconite and other debris lying upon the ice surface, 18 processed images of $5 \mathrm{~cm}$ thick surface ice samples removed using an ice axe were used instead.

Three bulk debris samples from the marginal ice zone and the Holocene blue ice zone at KG and from stakes 1, 7 and 11 at KPCL in the study of Bøggild and others (2010) were also disaggregated using sodium hexametaphosphate dispersing agent and subject to particle-size analysis using a Horiba laser diffraction sizer under standard manufacturer's operating conditions.

\section{Biological characterization}

Organic-matter content was analysed from the marginal and blue ice zones of the KG transect by standard loss-on-ignition at $450^{\circ} \mathrm{C}$. Bulk microbial biomass of two large samples collected from multiple cryoconite holes at both the KG blue ice zone and the KPCL Holocene ice was also undertaken. Our exact methodology is reported by Langford and others (2010), who also examined these samples. Briefly, $10 \mathrm{mg}$ cryoconite debris was suspended in $1 \mathrm{~mL}$ phosphate-buffered saline and incubated with DNA-specific fluorescent stain (DAPI), filtered onto a black $0.2 \mu \mathrm{m}$ filter and mounted on a glass slide. Analysis was undertaken under fluorescent light using a Zeiss Avioplan 2 epifluorescence microscope with a DAPI filter cube. Fifteen random fields of view were imaged and enumerated at $0.5 \mu \mathrm{m} \mathrm{Z}$ intervals. The autofluorescence of the photosynthesizing microorganisms was distinguished using an FTIC (fluorescein isothiocyanate) broad filter (Langford and others, 2010).

\section{Light and dark incubations}

Batch incubations of debris from the blue ice zone and marginal ice zone were employed in order to establish whether the microorganisms detected using the microscopy constituted an active community. We followed the exact methodology reported by Hodson and others (2010) and Telling and others (2010). Unfortunately, this could only be conducted at KG. Briefly, both the light and dark incubations were conducted on the ice, allowing direct estimation of net ecosystem production (NEP) and respiration (R), respectively. Primary production (PP) was then calculated by difference:

$$
\mathrm{NEP}=\mathrm{PP}-\mathrm{R} \text {. }
$$

Two sets of estimates were established for each batch of incubations. The first was based on total dissolved inorganic carbon (TDIC):

$$
\begin{gathered}
\mathrm{R}^{\mathrm{TDIC}}=\Delta \mathrm{TDIC}^{\text {dark }} \\
\mathrm{PP}^{\mathrm{TDIC}}=\Delta \mathrm{TDIC}^{\text {light }}-\mathrm{R}^{\mathrm{TDIC}} .
\end{gathered}
$$

The second was based on dissolved $\mathrm{O}_{2}$ :

$$
\begin{gathered}
\mathrm{R}^{\mathrm{O}_{2}}=-\Delta \mathrm{O}_{2}^{\text {dark }} \\
\mathrm{PP}^{\mathrm{O}_{2}}=-\mathrm{O}_{2}^{\text {light }}+\mathrm{R}^{\mathrm{O}_{2}} .
\end{gathered}
$$

The respiratory and photosynthesis quotients were assumed to be unity, so that $1 \mu \mathrm{M} \mathrm{O}_{2}$ consumption was assumed to result in $1 \mu \mathrm{M}$ TDIC during respiration (and vice versa during photosynthesis). All results were then expressed as a carbon flux ( $\mu \mathrm{C}^{-1} \mathrm{~d}^{-1}$ ) standardized to the dry mass ( $\mathrm{g}$ ) of the debris incubated. No significant mineral weathering contributions to TDIC and $\mathrm{O}_{2}$ changes were detected in the ion chemistry of the incubations. Light incubations were conducted in three $200 \mathrm{~mL}$ glass flasks, and dark incubations were conducted in three foil-wrapped bottles. Each batch was incubated for 1-3 days in large cryoconite holes during the interval 22 August-3 September 2008 (i.e. day of year (DOY) 235-247). An additional batch of seven dark incubations was also undertaken at $2^{\circ} \mathrm{C}$ over the course of 4 days to establish longer-term respiration rates. When all the incubations ended, $30 \mathrm{~mL}$ of sample was abstracted for TDIC analysis using the headspace method, and dissolved $\mathrm{O}_{2}$ was assessed immediately using a Hach luminescence dissolved-oxygen meter. Full analytical details are given by 
Table 1. Cryoconite hole characteristics for Kronprins Christians Land (KPCL), Kangerlussuaq (KG) and Thule Ramp. Values in parentheses are the number of observations. 'Mass per unit hole area' refers to the dry mass of entire cryoconite holes of different areas (see Methods)

\begin{tabular}{|c|c|c|c|c|}
\hline Parameter & KPCL all zones & KG blue ice & KG marginal ice zone & Thule area $(\mathrm{NE})^{\dagger}$ \\
\hline Ice cover (\%) & $(1-30)^{*}$ & $3.23 \pm 6.65(205)$ & $41.8 \pm 20.1(48)$ & - \\
\hline Hole depths $(\mathrm{cm})$ & $20 \pm 5.7^{*}$ & $24.3 \pm 9.4(23)$ & None found & $5-50$ \\
\hline Organic matter $(\%)$ & $5^{*}$ & $7.1 \pm 3.3(42)$ & $1.9 \pm 0.8(5)$ & $16.6 \pm 3.0(5)$ \\
\hline Mean size $(\mu \mathrm{m})$ & $33.0-35.3(3)$ & $42.0-75.6(3)$ & $105-108(3)$ & - \\
\hline Mode size $(\mu \mathrm{m})$ & $36.7-42.0(3)$ & $48.1-82.8(3)$ & $94.4-95.0(3)$ & \\
\hline $\begin{array}{l}\text { Total cells } \times 10^{3} \mathrm{mg}^{-1} \\
\text { Photoautotrophs } \times 10^{3} \text { : }\end{array}$ & $10.5 \pm 3.87$ & $2.08 \pm 1.83$ & - & $\begin{array}{c}\text { Abundant blue-green and green algae, } \\
\text { minor fungi/rotifers }\end{array}$ \\
\hline Filaments $\mathrm{mg}^{-1}$ & $0.53 \pm 0.68(30)$ & $0.41 \pm 0.58(30)$ & & \\
\hline Unicellular cells $\mathrm{mg}^{-1}$ & $0.47 \pm 0.40(30)$ & $0.012 \pm 0.12$ & & \\
\hline
\end{tabular}

*Values from Bøggild and others (2010). "Values from Gerdel and Drouet (1960).

Hodson and others (2010). Hourly irradiance at the ice surface was recorded with a Skye pyranometer and a Campbell Scientific 510 data logger.

\section{Hole evolution study}

In addition to the incubations, a spatial sampling programme of dissolved $\mathrm{O}_{2}$ in cryoconite holes was undertaken. This included the monitoring of two adjacent circular holes of near-identical area $\left(70.1\right.$ and $\left.73.1 \mathrm{~cm}^{2}\right)$ and initial depth (17 and $16 \mathrm{~cm}$, respectively). The dissolved oxygen, depth and water content of these holes was then followed over a 10 day period after removing all the cryoconite from one of the holes (hereafter the 'blank hole'). Differences between the holes were then used to assess NEP in the cryoconite community that was left behind in the other so-called 'occupied hole'.

\section{RESULTS}

\section{Mass distribution}

No cryoconite holes were found in the marginal ice zone at KG, where coarser particles with no aggregate structure and low organic-matter content dominated (Table 1). A far greater proportion of the ice surface was debris-covered here (average $42 \%$ ) than in the blue ice zone, where welldeveloped holes typically $15-60 \mathrm{~cm}$ deep (average $24 \mathrm{~cm}$ ) covered about $3.2 \%$ of the ice surface. Here the heterogeneity of cryoconite cover was far greater than in the marginal ice zone and values ranged from 0 to $39 \%$ of the ice surface in a similar manner to the blue ice at Thule Ramp and KPCL (Gerdel and Drouet, 1960; Bøggild and others, 2010). The mass loading within the cryoconite holes $\left(\sim 0.21 \mathrm{~g} \mathrm{~cm}^{-2}\right)$ was also very similar to the upper values reported by Bøggild and others (2010) at KPCL (see Table 1), yet was greater than other parts of this transect and several Svalbard glaciers (Cook and others, 2010). Reasons for this are unclear, but might reflect the thickness (not measured) and density of the debris. For example, Table 1 shows variable organic-matter content across the ice sheet, being greatest in the Thule area. Cryoconite densities might therefore be lowest here as a result of the reduced mineral contribution to the overall cryoconite volume. Table 1 also shows that the marginal ice of the KG transect was far coarser than any of the other sites upon the blue ice, where a greater proportion of particles less than $63 \mu \mathrm{m}$ was apparent. The marginal ice surface debris therefore appears to be derived from basal ice and moraine, rather than cryoconite derived from dust.

\section{Biology}

Bacteria, cyanobacteria and algae were identified in samples from both sites. Bacterial and photoautotroph abundance was greatest in cryoconite from KPCL, which also showed a proportionally greater content of unicellular photoautotrophs than cryoconite from KG. Microorganism abundance was greatest in samples with a high organic-matter content and percentage of fine-sized constituent particles (silt and clay), in agreement with a more complete analysis of these and other cryoconite samples reported by Langford and others (2010). The high standard deviations on the photoautotrophic counts represent the difficulty in disaggregating clusters of photoautotrophs, so the cell counts in Table 1 are indicative only. They do, however, confirm the presence of the significant microbial biomass suggested by pioneering work elsewhere in Greenland (Steinböck, 1936; Gerdel and Drouet, 1960).

\section{Hole evolution study}

Cold conditions occurred during this study, causing the formation of an ice lid over both the blank and occupied holes. Despite this, absorption of radiation by the occupied hole led to significant deepening relative to the blank hole (Fig. 2a). In fact, regression analysis suggests that the rate of deepening in the occupied hole was $1.32 \mathrm{~cm} \mathrm{~d}^{-1}$, almost ten times that observed in the blank hole $\left(0.14 \mathrm{~cm} \mathrm{~d}^{-1}\right.$, although in this case the regression model was not significant at $p=0.05$ ). Owing to the cold weather, measurement of dissolved $\mathrm{O}_{2}$ every afternoon (at $\sim 1500 \mathrm{~h}$ ) first required breaking the ice lid (which would soon form again and persist between measurements). It was therefore decided to fully equilibrate the two holes to the external atmosphere after $\mathrm{O}_{2}$ measurement by gentle stirring. Since a new ice lid would form after each daily measurement, no headspace formed above the water, so differences between the aqueous $\mathrm{O}_{2}$ mass of the two holes $\left(\Delta \mathrm{O}_{2}\right.$ in $\left.\mathrm{mg}\right)$ were the result of differential rates of hole wall melting $\left(\Delta \mathrm{O}_{2}\right.$ wall $)$ and NEP. Therefore:

$$
\Delta \mathrm{O}_{2}=\Delta \mathrm{O}_{2}{ }^{\text {wall }}+\mathrm{NEP}^{\mathrm{O}_{2}}
$$

and

$$
\Delta \mathrm{O}_{2}{ }^{\text {wall }}=12.13\left(\mathrm{~V}^{\text {cryo }}-\mathrm{V}^{\text {blank }}\right),
$$



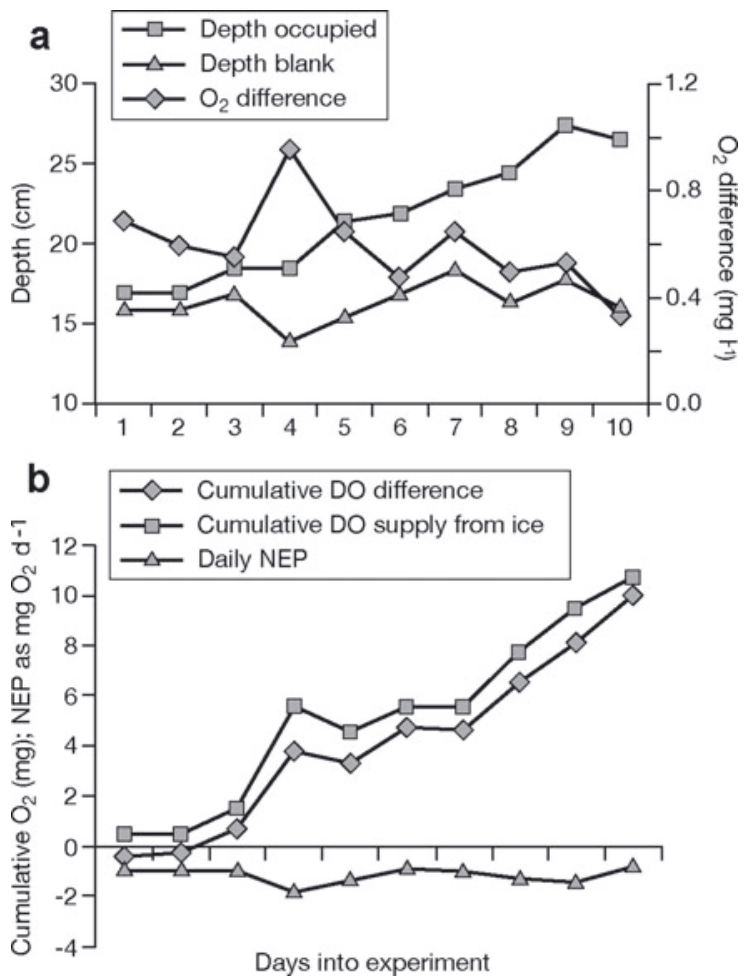

Fig. 2. Evolution of the blank and occupied cryoconite holes: (a) depths and $\mathrm{O}_{2}$ difference; (b) cumulative dissolved $\mathrm{O}_{2}$ difference and $\mathrm{O}_{2}$ supply from hole deepening, along with daily net ecosystem production (negative values indicate net respiration).

where 12.13 is the dissolved $\mathrm{O}_{2}$ of glacier ice at the site (in $\left.\mathrm{mg} \mathrm{L}^{-1}\right)$ and $\left(\mathrm{V}^{\text {cryo }}-\mathrm{V}^{\text {blank }}\right)$ is the daily increase in the occupied hole volume relative to the blank holes. $\mathrm{NEP}^{\mathrm{O}_{2}}$, in $\mathrm{mg} \mathrm{O}_{2}$, can be converted to $\mu \mathrm{g} \mathrm{Cg}^{-1} \mathrm{~d}^{-1}$ by assuming a respiratory quotient of 1 and standardizing to the dry mass of cryoconite in the hole $(8.9 \mathrm{~g})$. Daily $\mathrm{NEPO}_{2}$ and changes in $\Delta \mathrm{O}_{2}$ and $\Delta \mathrm{O}_{2}{ }^{\text {wall }}$ are depicted in Figure $2 \mathrm{~b}$. In spite of significant $\mathrm{O}_{2}$ supply during hole deepening, the $\mathrm{O}_{2}$ concentration was always lowest in the occupied hole, indicating that ecosystem activity was characterized by net respiration. The average $\mathrm{NEP}^{\mathrm{O}_{2}}$ was $-3.28 \pm 1.8 \mu \mathrm{MCg}^{-1} \mathrm{~d}^{-1}$ and can be compared with the incubation data presented below.

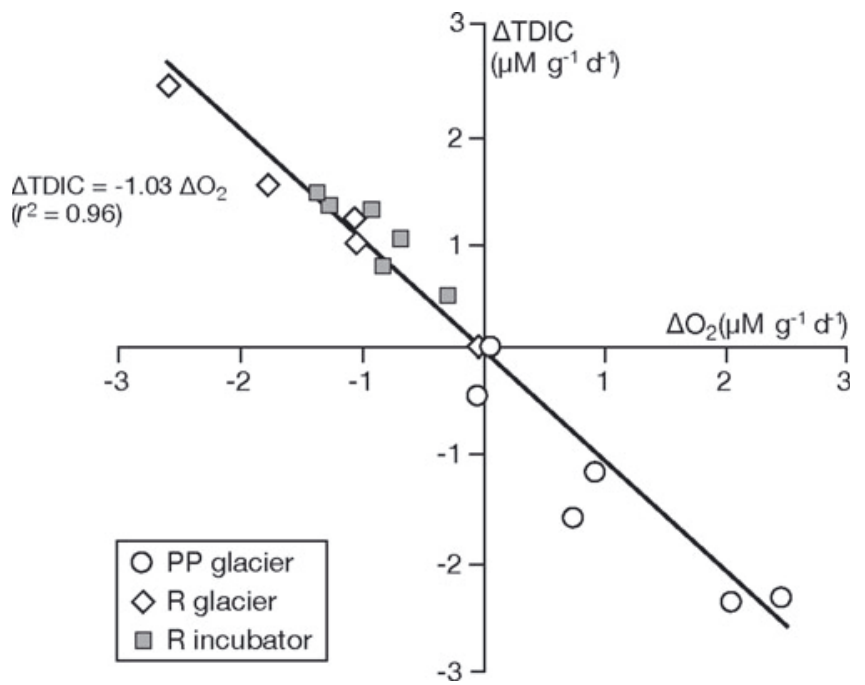

Fig. 3. Incubation results showing the values for respiration $(R)$ and photosynthesis (PP) deduced from changes in dissolved $\mathrm{O}_{2}$ ( $x$-axis) and TDIC ( $y$-axis). Legend: 'glacier' denotes the in situ incubations conducted at both the blue ice zone and the marginal zone (the latter plotting at the origin of the graph); 'incubator' denotes the 4 day dark incubation study.

\section{Incubations}

Table 2 and Figure 3 show the results of the light and dark incubations. Also included are respiration values for 4 day dark incubations at $2^{\circ} \mathrm{C}$. The data clearly show that while biological activity within the blue ice cryoconite was significant (respiration rates $1.03-2.6 \mu \mathrm{MC} \mathrm{g}^{-1} \mathrm{~d}^{-1}$ ), very little occurred in the marginal debris $\left(\leq 0.02 \mu \mathrm{MC} \mathrm{g}^{-1} \mathrm{~d}^{-1}\right)$. A strong relationship was also apparent between changes in dissolved $\mathrm{O}_{2}$ and TDIC, with a slope of -1.025 . This is marginally in excess of -1 , as a result of the slightly greater rates of $\mathrm{O}_{2}$ consumption relative to TDIC production during the 4 day dark incubations. Without these data, the slope of Figure 3 becomes -1.002 and therefore supportive of respiratory and photosynthesis quotients of unity.

NEP estimates according to the light bottle incubations were close to zero and therefore subject to large errors (not shown). The implication is that rates of photosynthesis were close to, but typically less than, the rates of respiration

Table 2. Respiration $\left(\mathrm{R}^{\mathrm{O}_{2}}, \mathrm{R}^{\mathrm{TDIC}}\right)$, net ecosystem production $\left(\mathrm{NEP}^{\mathrm{O}_{2}}, \mathrm{NEP}{ }^{\mathrm{TDIC}}\right)$ and photosynthesis $\left(\mathrm{PP}^{\mathrm{O}_{2}}, \mathrm{PP}^{\mathrm{TDIC}}\right)$ according to dissolved $\mathrm{O}_{2}$ and TDIC changes, respectively. BI denotes data for the blue ice zone and $\mathrm{M}$ for the marginal ice zone. $\mathrm{OH}$ is the occupied hole, RS is the 4 day dark incubation at $2{ }^{\circ} \mathrm{C}$, IR is the average incident radiation throughout the incubations and $\mathrm{d}$ the duration in days. The end dates (in 2008) of the incubations are shown in parentheses, and negative NEP values show an excess of respiration over photosynthesis

\begin{tabular}{|c|c|c|c|c|c|c|c|c|}
\hline Batch & $d$ & $\begin{array}{c}\mathrm{R}^{\mathrm{O}_{2}} \\
\mu \mathrm{Mg}^{-1} \mathrm{~d}^{-1}\end{array}$ & $\begin{array}{c}\mathrm{R}^{\mathrm{TDIC}} \\
\mu \mathrm{Mg}^{-1} \mathrm{~d}^{-1}\end{array}$ & $\begin{array}{c}\mathrm{NEP}^{\mathrm{O}_{2}} \\
\mu \mathrm{Mg}^{-1} \mathrm{~d}^{-1}\end{array}$ & $\begin{array}{c}\text { NEP }{ }^{\text {TDIC }} \\
\mu \mathrm{Mg}^{-1} \mathrm{~d}^{-1}\end{array}$ & $\begin{array}{c}\mathrm{PP}_{2} \\
\mu \mathrm{Mg}^{-1} \mathrm{~d}^{-1}\end{array}$ & $\begin{array}{c}\text { PP TDIC } \\
\mu \mathrm{Mg}^{-1} \mathrm{~d}^{-1}\end{array}$ & $\begin{array}{c}\text { IR } \\
W \mathrm{~m}^{-2}\end{array}$ \\
\hline BI 1 (to 24 Aug) & 2 & $1.06 \pm 0.35$ & $1.22 \pm 0.08$ & $-1.11 \pm 0.53$ & $-0.83 \pm 0.082$ & -0.053 & 0.39 & 80 \\
\hline BI 2 (to 27 Aug) & 3 & $1.03 \pm 0.23$ & $1.02 \pm 0.15$ & $-0.08 \pm 0.064$ & $0.11 \pm 0.020$ & 0.94 & 1.13 & 155 \\
\hline BI 3 (to 29 Aug) & 2 & $2.60 \pm 0.25$ & $2.46 \pm 0.10$ & $-0.54 \pm 0.11$ & $-0.14 \pm 0.085$ & 2.06 & 2.32 & 152 \\
\hline BI 4 (to 30 Aug) & 1 & $1.78 \pm 0.41$ & $1.53 \pm 0.79$ & $-1.02 \pm 0.55$ & $0.042 \pm 0.08$ & 0.76 & 1.57 & 157 \\
\hline BI 5 (to $01 \mathrm{Sep}$ ) & 2 & $2.60 \pm 0.07$ & $2.46 \pm 0.12$ & $-0.11 \pm 0.067$ & $-0.07 \pm 0.045$ & 2.49 & 2.39 & 175 \\
\hline M (to 02 Sep) & 1 & $0.016 \pm 0.001$ & $0.01 \pm 0.01$ & $0.01 \pm 0.002$ & $0.01 \pm 0.009$ & 0.023 & 0.012 & 127 \\
\hline $\mathrm{OH}$ (to $02 \mathrm{Sep}$ ) & 10 & - & - & $-3.28 \pm 1.8$ & - & - & - & 52 \\
\hline RS (to $02 \mathrm{Sep}$ ) & 4 & $0.84 \pm 0.41$ & $1.03 \pm 0.36$ & - & - & - & - & 0 \\
\hline
\end{tabular}


occurring in the incubations. Further, the average $\mathrm{NEP}^{\mathrm{O}_{2}}$ for the hole evolution study $\left(-3.28 \mu \mathrm{Mg}^{-1} \mathrm{~d}^{-1}\right)$ was three times greater than the highest $\mathrm{NEPO}_{2}$ estimate from the blue-ice light incubations. It is unclear whether the bottle incubations or the hole evolution study are subject to the greatest uncertainty. However, a robust observation is that estimates of $\mathrm{NEP}^{\mathrm{O}_{2}}$ from both the incubations and the hole evolution study were negative and therefore show net respiration during the field campaign.

\section{DISCUSSION}

\section{Biological production and net carbon balance}

The carbon transfers typical of the blue ice zone in Table 2 clearly indicate biological production associated with cryoonite debris upon the GIS. However, the coarser marginal debris was notable for its negligible PP and $R$ according to our methods. The implication therefore is that sediment source and environmental factors such as the flushing rate by meltwater (e.g. Stibal and others, 2010) are important for supporting biological activity upon the ice surface.

Results from the hole evolution study show how the onset of freezing air temperatures during this campaign ensured that radiative warming of the cryoconite debris was the most significant source of heat for melting near the ice surface. As a result, quite significant deepening of the cryoconite holes occurred beneath their ice lids, an effect that formed the basis of Gribbon's (1979) work on cryoconite thermodynamics. Here we wish to show that these effects are also important in the context of biological processes because the deepening liberates new nutrients, oxygen and TDIC for biological production from the glacier ice wall (cf. Tranter and others, 2004) and reduces the light incident upon the photosynthesizing microorganisms in the cryoconite. For example, Figure 2a shows how the depth of the occupied hole increased by $60 \%$ over 10 days, causing a depth difference between the two holes that was strongly correlated to cumulative solar radiation receipt at the ice surface $\left(p=1 \times 10^{-6}, n=9\right)$. Further, while Figure $2 \mathrm{~b}$ shows that $\mathrm{O}_{2}$ supply from the ice melt was the dominant term in the $\mathrm{O}_{2}$ balance of the occupied hole, respiration still maintained a significantly lower dissolved $\mathrm{O}_{2}$ concentration compared with the blank hole (Fig. 2a). Therefore, lower light penetration down to cryoconite within rapidly deepening ice-lidded cryoconite holes is most likely to have been responsible for maintaining net respiration throughout this experiment. We believe that this explains why the correlation between photosynthesis and irradiance in our incubations was weak $(p=0.08, n=5)$. It is also very probable that our study has not captured photosynthesis rates at their maximum, since these are most likely promoted by higher air temperatures during the main melt season, when shallower cryoconite holes are likely to be open and subjected to greater levels of irradiance. For example, photosynthesis rates presented in Anesio and others (2009) are up to an order of magnitude greater and include a value of $9.6 \mu \mathrm{Mg}^{-1} \mathrm{~d}^{-1}$ from Frøya Glacier near Zackenberg (Fig. 1). Therefore, the use of our incubation measurements for the estimation of carbon fluxes at the icesheet scale is likely to be more uncertain for photosynthesis than for respiration.

\section{A basic model of biologically mediated carbon transfers on the GIS}

Abundant cryoconite in the northeast, northwest and southwest quarters of the ice sheet, coupled with our new evidence of biological activity during the summer, clearly suggest that ice-sheet carbon fluxes deserve attention, not least because Anesio and others (2009) have proposed a global impact of cryoconite NEP equivalent to $65 \mathrm{Gg} \mathrm{Ca}^{-1}$. In order to assess the GIS contribution to this potential flux for the first time, we modified a basic carbon budget model developed by Hodson and others (2007) so that the potential carbon fluxes associated with respiration $\left(\mathrm{CR}^{\text {snow }}\right.$ and $\left.\mathrm{CR}^{\text {ice }}\right)$ and photosynthesis ( $\mathrm{CP}^{\mathrm{ice}}$ ) could be estimated thus:

$$
\begin{gathered}
\mathrm{CR}^{\text {snow }}=A_{\text {bio }}(1-i) M_{d} C \mathrm{R}^{\text {snow }} d_{m} k, \\
\mathrm{CP}^{\text {ice }}=A_{\text {bio }}(i) M_{d} c \mathrm{PP}^{\text {ice }} d_{m} k, \\
\mathrm{CR}^{\text {ice }}=A_{\text {bio }}(i) M_{d} C \mathrm{R}^{\text {ice }} d_{m} k .
\end{gathered}
$$

$\mathrm{CR}^{\text {snow }}$ represents respiration by cryoconite beneath saturated snow or slush, and $C R^{\text {ice }}$ represents respiration when cryoconite is exposed by snow retreat and photosynthesis is possible $\left(\mathrm{CP}^{\text {ice }}\right)$. $A_{\text {bio }}$ represents the area of the ice sheet covered in wet, biologically active cryoconite debris, $i$ is the proportion of this zone that is no longer snow-covered, $M_{d}$ is the mass per unit area of cryoconite $\left(\mathrm{g} \mathrm{cm}^{-2}\right)$ and $c$ is the percentage cover of cryoconite within $A_{\text {bio. }}$. ${ }^{\text {snow }}$ and $\mathrm{R}^{\text {ice }}$ are respiration rates before and after removal of snow cover, respectively, whilst $\mathrm{PP}^{\text {ice }}$ is the rate of photosynthesis after snow-cover removal (all in $\mu \mathrm{MCg}^{-1} \mathrm{~d}^{-1}$ ). The term $d_{m}$ represents the time-step of the calculations in days, and $k$ is a constant of 1200 for unit conversion.

There are major uncertainties in almost all the parameters defined above, so we restricted our calculations to the basics by using fixed values of $\mathrm{R}^{\text {snow }}, \mathrm{R}^{\text {ice }}$ and $\mathrm{PP}^{\text {ice }}$ and a monthly time-step. The maximum extent of $A_{\text {bio }}$ was assumed to be equivalent to the average end-of-summer bare ice zone over the interval 2001-08. The basal ice zone was ignored on account of the surface area being trivial. The growth of $A_{\mathrm{bio}}$ and its bare ice proportion, $i$, were achieved by driving the runoff-retention model of Janssens and Huybrechts (2000) at a $5 \mathrm{~km} \times 5 \mathrm{~km}$ spatial resolution using downscaled European Centre for Medium-Range Weather Forecasts (ECMWF) meteorological (re)analysis data and empirically derived ice-sheet-surface lapse rates. Full details of this process are given by Hanna and others (2005). The typical end-ofsummer expanses of $A_{\mathrm{bio}}(1-i)$ (slush) and $A_{\mathrm{bio}}(i)$ (bare ice) are shown in Figure 1.

The fixed values of $M_{d}\left(0.2 \mathrm{~g} \mathrm{~cm}^{-2}\right), c(3 \%), \mathrm{R}^{\text {snow }}, \mathrm{R}^{\text {ice }}$ (both $\left.1.74 \mu \mathrm{MCg}^{-1} \mathrm{~d}^{-1}\right)$ and PPice $\left(1.56 \mu \mathrm{MCg}^{-1} \mathrm{~d}^{-1}\right)$ used initially were average values for the blue zone in Tables 1 and 2. The product of $M_{d}$ and $c$ implies an impurity loading of $66 \mathrm{~g} \mathrm{~m}^{-2}$, which can be compared to the range $16-1400 \mathrm{~g} \mathrm{~m}^{-2}$ derived for the $\mathrm{KPCL}$ transect by Bøggild and others (2010) and the $25 \mathrm{~g} \mathrm{~m}^{-2}$ estimate used to represent all glacier ice ablation areas outside Antarctica by Anesio and others (2009). It is appreciated that fixed values are unlikely and that $R^{\text {snow }}$ and $R^{\text {ice }}$ might not be the same. However, there are simply no data as yet to improve these estimates and we only seek indicative flux estimates in this study.

The model described above resulted in values for $\mathrm{CR}^{\text {snow }}$, $\mathrm{CP}^{\text {ice }}$ and $\mathrm{CR}^{\text {ice }}$ that are shown in Table 3. The resultant NEP fluxes are also shown. In addition, results for a second 
Table 3. Annual carbon fluxes (in $\left.\mathrm{Gg} \mathrm{Ca}{ }^{-1}\right)$ for respiration in snow and bare ice habitats $\left(\mathrm{CR}^{\text {snow }}\right.$ and $\mathrm{CR}^{\text {ice }}$ ) and photosynthesis upon bare ice (CP ${ }^{\text {ice }}$ and $\left.{ }^{\text {Max }} \mathrm{CP}^{\text {ice }}\right)$. NEP I is $\left(\mathrm{CP}^{\text {ice }}-\mathrm{CR}^{\text {ice }}-\mathrm{CR}^{\text {snow }}\right)$ and NEP II is ( $\left.{ }^{\text {Max }} \mathrm{CP}^{\text {ice }}-\mathrm{CR}^{\text {ice }}-\mathrm{CR}^{\text {snow }}\right)$

\begin{tabular}{|c|c|c|c|c|c|c|}
\hline Year & $\mathrm{CR}^{\text {snow }}$ & $\mathrm{CR}^{\text {ice }}$ & $C P^{\text {ice }}$ & ${ }^{\operatorname{Max}} \mathrm{CP}^{\mathrm{ice}}$ & NEP I & NEP II \\
\hline 2001 & 2.06 & 23.5 & 21.1 & 192 & -4.48 & 166.0 \\
\hline 2003 & 3.56 & 23.7 & 21.2 & 193 & -6.00 & 165.8 \\
\hline 2004 & 2.84 & 22.2 & 19.9 & 180 & -5.12 & 155.3 \\
\hline 2005 & 3.21 & 18.5 & 16.6 & 150 & -5.11 & 128.4 \\
\hline 2007 & 2.93 & 20.2 & 18.1 & 164 & -5.01 & 141.3 \\
\hline 2008 & 3.39 & 21.8 & 19.6 & 178 & -5.64 & 152.6 \\
\hline Mean & 3.10 & 21.72 & 19.5 & 177 & -5.33 & 152.1 \\
\hline Std dev. & 0.63 & 2.27 & 2.04 & 18.73 & -0.54 & 16.79 \\
\hline
\end{tabular}

scenario are included that try to account for the clear evidence that PP is low in our dataset. For this scenario, PPice was $14.7 \mu \mathrm{MC} \mathrm{g}^{-1} \mathrm{~d}^{-1}$, the average rate of PP deduced from non-lidded cryoconite holes for a selection of Svalbard, Greenland and Austrian glaciers by Anesio and others (2009). This was used to yield a high fixation rate across the GIS ( ${ }^{\text {Max }} \mathrm{CP}^{\text {ice }}$ ). Table 3 shows that respiration fluxes are approximately ten times greater from bare ice surfaces than from slush-buried surfaces, largely because $A_{\text {bio }}$ rapidly loses its snow cover during the summer and we have been conservative when defining its extent $\left(202000 \mathrm{~km}^{2}\right.$ or $12 \%$ of the GIS). Total respiration fluxes of the order of $25 \mathrm{Gg} \mathrm{Ca}^{-1}$ result, representing much of the glacial respiration flux of $35 \mathrm{Gg} \mathrm{Ca}^{-1}$ proposed by Anesio and others (2009) for all glaciers outside Antarctica. However, the outcome is less clear for carbon fixation by photosynthesis, being $\sim 20 \mathrm{Gg} \mathrm{Ca} \mathrm{a}^{-1}$ according to our incubation data and $180 \mathrm{Gg} \mathrm{Ca}^{-1}$ using average values from Anesio and others (2009). The impact of this uncertainty upon net ecosystem demand for carbon is very significant, with estimates ranging from a net respiration flux of $-5.3 \mathrm{GgC}^{-1}$ to a net carbon sink of $152 \mathrm{Gg} \mathrm{Ca}^{-1}$. Therefore, significant carbon fluxes (at the $10^{1}-10^{2} \mathrm{Gg} \mathrm{Ca}^{-1}$ range) are likely to be associated with biological production upon the GIS, but since we have no evidence to suggest that the rates presented by Anesio and others (2009) are representative, we tentatively suggest that the lower values are the most realistic. More research on spatio-temporal changes in cryoconite ecosystem activity across the ice sheet are clearly required to test this assertion, especially for evaluating the rates of photosynthesis.

\section{CONCLUSIONS}

Mass-loading estimates in the vicinity of KPCL (Bøggild and others, 2010) and KG (this study) have produced the first estimates of cryoconite distribution across the melt zone of the GIS. We find $\sim 66 \mathrm{~g} \mathrm{~m}^{-2}$ of cryoconite near the ice margin at KG, which is within the range $17-400 \mathrm{~g} \mathrm{~m}^{-2}$ for ice blocks analysed by Bøggild and others (2010) in the KPCL area. As elsewhere (e.g. Thule Ramp: Gerdel and Drouet, 1958), this cryoconite includes a significant microbial biomass (up to $10 \%$ organic matter by mass and $10^{3}-10^{4}$ cells $\mathrm{mg}^{-1}$ ) indicative of both an autotrophic and heterotrophic community. Biological activity was therefore estimated in the KG area during late summer, producing respiration rates $\left(1.0-2.5 \mu \mathrm{MCg}^{-1} \mathrm{~d}^{-1}\right)$ that were marginally in excess of photosynthesis $\left(0.39-2.4 \mu \mathrm{MC} \mathrm{g}^{-1} \mathrm{~d}^{-1}\right)$ and thus indicative of net respiration. The same state was also apparent from dissolved $\mathrm{O}_{2}$ balance calculations in cryoconite holes measured in situ. This means biologically mediated $\mathrm{CO}_{2}$ fluxes into (photosynthesis) and out of (respiration) the ice-sheet surface are far from trivial at the ice-sheet scale, being $10^{1}-10^{2} \mathrm{Gg} \mathrm{Ca}^{-1}$ when our data are coupled to a well-known surface mass-balance model that estimates the expansion of the biologically active bare ice and slush zones. However, the net impact upon atmospheric $\mathrm{CO}_{2}$ is impossible to determine until the rates of biological activity, especially photosynthesis, across the ice sheet during summer are better understood.

\section{ACKNOWLEDGEMENTS}

A. Hodson acknowledges a Leverhulme Trust Research Fellowship (RF/4/RFG/2007/0398) and UK Natural Environment Research Council grant (NE/G006253/1). J. Yde is thanked for his help in the field.

\section{REFERENCES}

Anesio, A.M., A.J. Hodson, A. Fritz, R. Psenner and B. Sattler. 2009. High microbial activity on glaciers: importance to the global carbon cycle. Global Change Biol., 15(4), 955-960.

Bayley, W.S. 1891. Minerology and petrography. Am. Natur., 25(290), 138-146.

Bøggild, C.E., R.E. Brandt, K.J. Brown and S.G. Warren. 2010. The ablation zone in northeast Greenland: ice types, albedos and impurities. J. Glaciol., 56(195), 101-113.

Cook, J., A. Hodson, J. Telling, A. Anesio, T. Irvine-Fynn and C. Bellas. 2010. The mass-area relationship within cryoconite holes and its implications for primary production. Ann. Glaciol., 51(56) (see paper in this issue).

De Quervain, A. and 6 others. 1920. Résultats scientifiques de I'Expédition Suisse au Groenland 1912-1913. Denkschr. Schweiz. Naturforsch. Ges., 53.

Gajda, R.T. 1958. Cryoconite phenomena on the Greenland Ice Cap in the Thule area. Can. Geogr., 3(12), 35-44.

Gerdel, R.W. and F. Drouet. 1960. The cryoconite of the Thule area, Greenland. Trans. Am. Microsc. Soc., 79, 256-272.

Gribbon, P.W.F. 1979. Cryoconite holes on Sermikavsak, West Greenland. J. Glaciol., 22(86), 177-181.

Hanna, E., P. Huybrechts, I. Janssens, J. Cappelen, K. Steffen and A. Stephens. 2005. Runoff and mass balance of the Greenland 
ice sheet: 1958-2003. J. Geophys. Res., 110(D13), D13108. (10.1029/2004JD005641.)

Hobbs, W.H. 1910. Characteristics of the inland-ice of the Arctic regions. Proc. Am. Philos. Soc., 49(194), 57-129.

Hodson, A.J. and 10 others. 2007. A glacier respires: quantifying the distribution and respiration $\mathrm{CO}_{2}$ flux of cryoconite across an entire Arctic supraglacial ecosystem. J. Geophys. Res., 112(G4), G04S36. (10.1029/2007JG000452.)

Hodson, A. and 6 others. 2010. The structure, biological activity and biogeochemistry of cryoconite aggregates upon an Arctic valley glacier: Longyearbreen, Svalbard. J. Glaciol., 56(196), 349-362.

Irvine-Fynn, T.D.L., J.W. Bridge and A.J. Hodson. 2010. Rapid quantification of cryoconite: granule geometry and in situ supraglacial extents, using examples from Svalbard and Greenland. J. Glaciol., 56(196), 297-308.

Janssens, I. and P. Huybrechts. 2000. The treatment of meltwater retardation in mass-balance parameterizations of the Greenland ice sheet. Ann. Glaciol., 31, 133-140.
Langford, H., A. Hodson, S. Banwart and C. Bøggild. 2010. The microstructure and biogeochemistry of Arctic cryoconite granules. Ann. Glaciol., 51(56) (see paper in this issue).

Steinböck, O. 1936. Über Kryokonitlöcher und ihre biologische Bedeutung. Z. Gletscherkd., 24, 1-21.

Stibal, M., G.P. Lis, E. Lawson, K.M. Mak, J.L. Wadham and A.M. Anesio. 2010. Organic matter content and quality in supraglacial debris across the ablation zone of the Greenland ice sheet. Ann. Glaciol., 51(56) (see paper in this issue).

Telling, J. and 7 others. 2010. Measuring rates of gross and net rates of photosynthesis in cryoconite holes: a comparison of field methods. Ann. Glaciol., 51(56) (see paper in this issue).

Tranter, M. and 6 others. 2004. Extreme hydrochemical conditions in natural microcosms entombed within Antarctic ice. Hydrol. Process., 18(2), 379-387.

Von Drygalski, E. 1897. Die Kryoconitlöcher. In von Drygalski, E., ed. Grønland-Expedition der Gesellschaft für Erdkunde zu Berlin 1891-1893. Vol. 1. Berlin, W.H. Kühl, 93-103. 